\title{
First report of powdery mildew caused by Erysiphe convolvuli on Calystegia hederacea in Korea
}

\author{
Sun-Hee Hong ${ }^{1} \cdot$ Young-Ho Lee ${ }^{1} \cdot$ Young-Joon $\mathrm{Choi}^{2} \cdot$ Hyeon-Dong Shin ${ }^{3}$ \\ Received: 4 July 2020 / Accepted: 10 September 2020 / Published online: 12 October 2020 \\ (C) Società Italiana di Patologia Vegetale (S.I.Pa.V.) 2020
}

Keywords Calystegia hederacea $\cdot$ Powdery mildew symptoms $\cdot$ Ascospores

In 2016-2019, Erysiphe convolvuli DC. was observed on Calystegia hederacea Wall. (a noxious weed) in four localities in Korea, including a public garden in Seoul. Previously E. convolvuli was recorded on several species of Calystegia in Europe and China (Farr and Rossman 2020). Powdery mildew symptoms were observed on leaves and stems of C. hederacea. Initially the infected plants displayed white powdery spots on both sides of leaves and on stems. As the disease progressed, the spots grew larger and denser. Eventually, the leaves turned yellow and proceeded to die or fall off. Conidiophores, which arose from epiphytic hyphae, were straight, 3-4-celled, 60-114 × 7-9 $\mu \mathrm{m}$, with straight foot cells $25-35 \mu \mathrm{m}$ long. Conidia, formed in chains, were cylindrical to ellipsoid-cylindrical, 32-48 $\times 14-20 \mu \mathrm{m}$. Chasmothecia, scattered to gregarious, were formed on leaves and stems in autumn. They were 80-124 $\mu \mathrm{m}$ diameter, with 10-40 appendages in the lower half of the ascomata. Appendages were mycelioid, simple, or sometimes 1-2 times irregularly branched, interlaced with each other, with walls hyaline, thin, smooth to rough, sometimes with the lower half pigmented yellowish to brownish, septate, 4-8 $\mu \mathrm{m}$ wide. Asci were 4-8, sessile or short-stalked, broad ellipsoid-ovoid, saccate, 50-64 × 30-40 $\mu \mathrm{m}, 4-6$-spored. Ascospores were ellipsoid-ovoid, 16-24 × 12-16 $\mu \mathrm{m}$, and colorless (Braun and Cook 2012). The ITS1/2 rDNA and LSU rDNA regions were amplified and sequenced with ITS5/P3 and NL1/NLP2 (Mori

Hyeon-Dong Shin

hdshin@korea.ac.kr

1 Department of Plant and Environmental Science, Hankyong National University, Anseong 17579, South Korea

2 Department of Biology, Kunsan National University, Gunsan 54150, South Korea

3 Division of Environmental Science and Ecological Engineering, Korea University, Seoul 02841, South Korea et al. 2000) primers, respectively. The ITS $1 / 2$ and LSU sequences showed $99-100 \%$ similar to E. convolvuli (AB104518, LC270835, LC270857, LC328325). Voucher specimens were deposited in the Korea University Herbarium (KUS). Both sequences were deposited in GenBank (Accession No. MT377709, MT380913). This is the first report of powdery mildew caused by E. convolvuli on $C$. hederacea in Korea.

\section{Compliance with ethical standards}

Conflict of interest The authors declare that they have no conflict of interest.

\section{References}

Braun U, Cook RTA (2012) Taxonomic manual of the Erysiphales (powdery mildews), CBS Biodiversity Series No. 11. CBS, Utrecht

Farr DF, Rossman AY (2020) Fungal databases, syst. Mycol. Microbiol. Lab., Online publication. ARS, USDA. Retrieved July 2, 2020

Mori Y et al (2000) Evolutionary analysis of the powdery mildew fungi (Erysiphales) using nucleotide sequences of the nuclear ribosomal DNA. Mycologia 92:74-93

Publisher's note Springer Nature remains neutral with regard to jurisdictional claims in published maps and institutional affiliations. 